\title{
latrogenic Cushing Syndrome due to Application of Potent Topical Corticosteroid: A Case Report
}

\author{
Bhusal M¹, Aryal E', Bhattarai S', Shrestha SB'1, Rajouria A $^{2}$
}

${ }^{1}$ Department of Dermatology, Kathmandu Medical College Teaching Hospital, Sinamangal, Kathmandu, Nepal; ${ }^{2} \mathrm{Nepal}$ Diabetes Endocrinology and Physician Center, New Baneshwor, Kathmandu, Nepal

\begin{abstract}
Corticosteroids are over the counter and cheaper drugs available in every medical stores in Nepal. latrogenic Cushing syndrome due to topical steroids application is a very rare phenomenon in adults. A 32 year female from Janakpur presented with complaints of swelling of face, weight gain, excessive facial hair and fatigue since two years that gradually increased over last one year. She had a past medical history of on and off application of multiple potent topical corticosteroids for disseminated Tinea infection. She was obese with moon facies, buffalo hump and multiple striae over her abdomen. Her blood pressure was raised and her blood sugar was in pre-diabetic range. Laboratory studies were consistent with iatrogenic Cushing syndrome. Patient recovered after discontinuation of topical corticosteroids and treatment with antifungals. Although iatrogenic Cushing syndrome following application of topical corticosteroid is a rare phenomenon in adults, this can happen in a setup like ours where corticosteroids are prescribed as over the counters and patients have very little knowledge about their use. Therefore, we emphasize that patients and pharmacist should be well educated about the consequences of their prolong application and their side effects.
\end{abstract}

Key words: Adrenocorticotropic hormone; Clobetasol; Pituitary-adrenal system

\section{Introduction}

C orticosteroids are anti-inflammatory group of drugs prescribed for a wide range of dermatological conditions e.g. Eczemas, Psoriasis, Bullous Dermatosis, Connective tissue diseases, Vasculitis etc. ${ }^{1}$ They are available in topical and systemic (Intralesional, Oral, Intravenous, Intramuscular) forms. Topical Corticosteroids are over the counter and cheaper drugs available in every medical stores in Nepal and India and often misused for treatment of Dermatophytic infections, Eczemas, Acne, undiagnosed skin rashes and as fairness cream by non-registered practitioners/ chemist. 2,3,4 In a Tertiary hospital in Nepal, almost $74.4 \%$ had used topical steroid cream on face from recommendation of friends/pharmacist or from over the counter purchase. $^{5}$ In 2014-15 there was a sale worth $\$ 234$ million in India which accounted for almost $82 \%$ of total dermatological product sale in the country. ${ }^{2,3}$ Topical corticosteroids have various local side effects (skin atrophy, erythema,

\footnotetext{
Address of Correspondence

Dr. Mohan Bhusal

Resident

Department of Dermatology

Kathmandu Medical College Teaching Hospital, Sinamangal Kathmandu.

E-mail: bhusalmohan1@gmail.com
}

telangeictasia, acneiform eruptions, hypertrichosisetc) and rarely systemic side effects (suppression of hypothalamo pituitary adrenal axis, iatrogenic cushing syndrome, growth retardation etc.) on long term use at supraphysiological dosage. ${ }^{1}$ latrogenic Cushing syndrome due to topical steroids application is a very rare phenomenon reported in adults. ${ }^{6}$ We report a case of a 32 year female with iatrogenic Cushing syndrome.

\section{Case report}

32 year old female from Janakpur presented at Nepal Diabetes Thyroid Endocrinology and Physician Center

Submitted: $30^{\text {th }}$ October 2018

Accepted: $1^{\text {st }}$ February 2019

Published: 31 $1^{\text {st }}$ March 2019

How to cite this article

Bhusal M, Aryal E, Bhattarai S, Shrestha SB, Rajouria A. latrogenic cushing syndrome due to application of potent topical corticosteroid: A case report. Nepal. Nepal Journal of Dermatology, Venereology and Leprology. 2019;17(1):73-5. doi: http://dx.doi. org/10.3126/njdvl.v17i1.23291

\section{(c) (i)}

Licensed under CC BY 4.0 International License which permits use, distribution and reproduction in any medium, provided the original work is properly cited. 
(NDEP), New Baneshwor, Kathmandu with swelling of face, weight gain, excessive facial hair, generalized fatigue and weakness of arms since two years that gradually increased over the last one year. She had a past medical history of repeated application of multiple potent topical corticosteroids for disseminated tinea infection since nine years and more intense and regular application of clobetasol propionate $0.05 \%$ cream for last one year (approximately 56 tubes of $30 \mathrm{~g}$ in last 6 months; i.e $70 \mathrm{~g}$ per week). For the management of Tine a infection, she was referred to Kathmandu Medical College Teaching Hospital (KMCTH). There was no history of intake of any other forms of steroid. On examination she was Grade II overweight (BMI= $32 \mathrm{~kg} / \mathrm{m}^{2}$ ) with truncal obesity. She had gained $20 \mathrm{~kg}$ over 6 months. Her blood pressure was 150/90 mm of $\mathrm{Hg}$. Moon facies, hypertrichosis (fig.3.), buffalo hump (fig.3.) and multiple striae (fig.1.) over abdomen were present. On investigation her $\mathrm{HbA1c}$ was $6.1 \%$ (N:

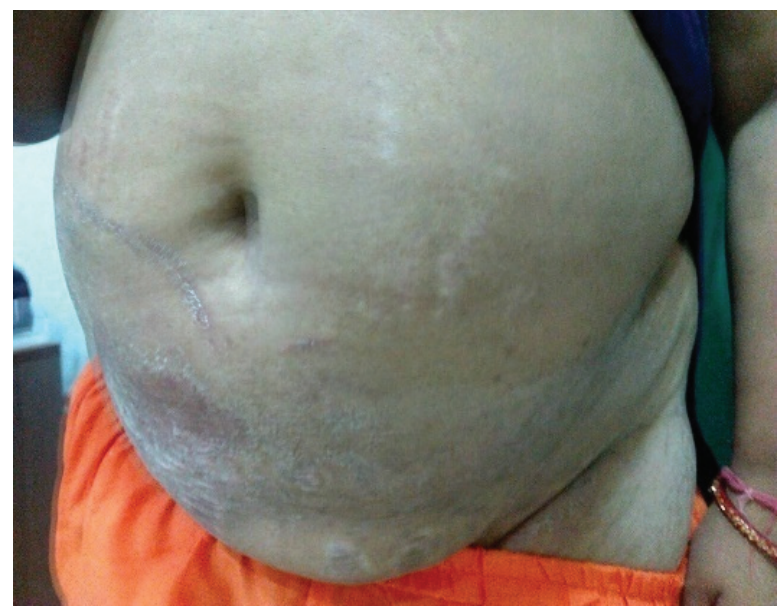

Figure 1: Tinea corporis, Abdominal striae and centeral obesity before treatment

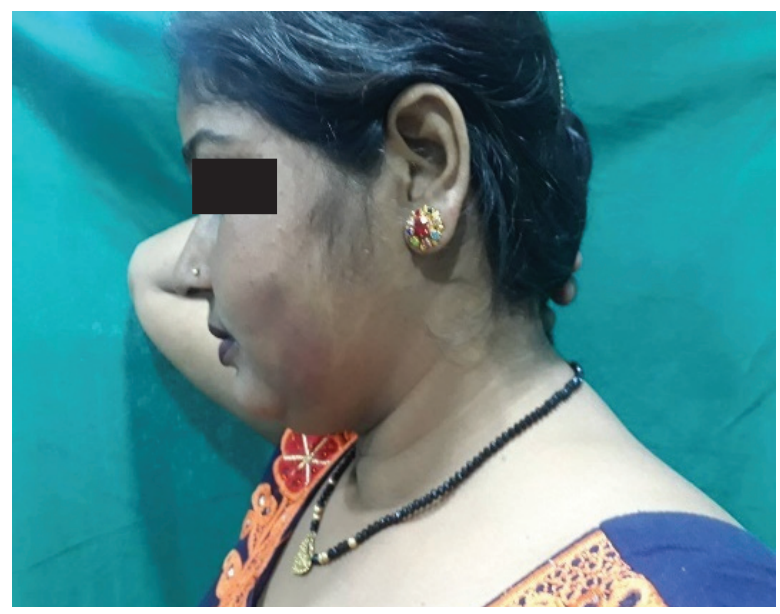

Figure 3: Buffalo hump before treatment
4-5.6), 8 am cortisol was $0.32 \mu \mathrm{g} / \mathrm{dl}(6.9-22.6 \mu \mathrm{g} / \mathrm{dl}), 4$ pm cortisol was $0.48 \mu \mathrm{g} / \mathrm{dl}(6.7-22.6 \mu \mathrm{g} / \mathrm{dl}) ; 24$ hour urinary cortisol was $9.5 \mu \mathrm{g} / \mathrm{dl}(20.9-290.3 \mu \mathrm{g} / \mathrm{dl})$ and ACTH was $17.1 \mathrm{pg} / \mathrm{ml}(\leq 46 \mathrm{pg} / \mathrm{ml})$. These biochemical parameters were suggestive of suppressed HPAAxis (secondary to exogenous corticosteroid). Primary (adrenal) or secondary (pituitary) hyper/ hypocortisolism being excluded.

Patient was started on oral itraconazole 200mg twice daily, butenafine cream twice daily, clotrimazole dusting powder, oral anti histaminic and calcium supplementation. Topical steroid was discontinued. After three months, Patient lost $11 \mathrm{~kg}$ weight, her blood pressure normalized. Buffalo hump (Fig 2), Abdominalstriae (fig 4) and hypertrichosis reduced to a great extent. The $\mathrm{HbA} 1 \mathrm{c}$ and 8 am cortisol normalized to $5.2 \%$ and $9.66 \mu \mathrm{g} / \mathrm{dl}$ respectively.

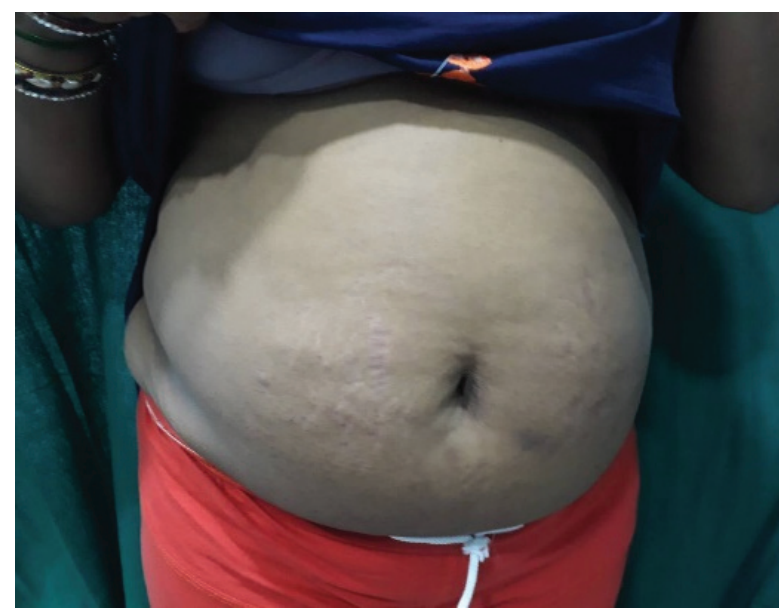

Figure 2: Abdominal striae after treatment

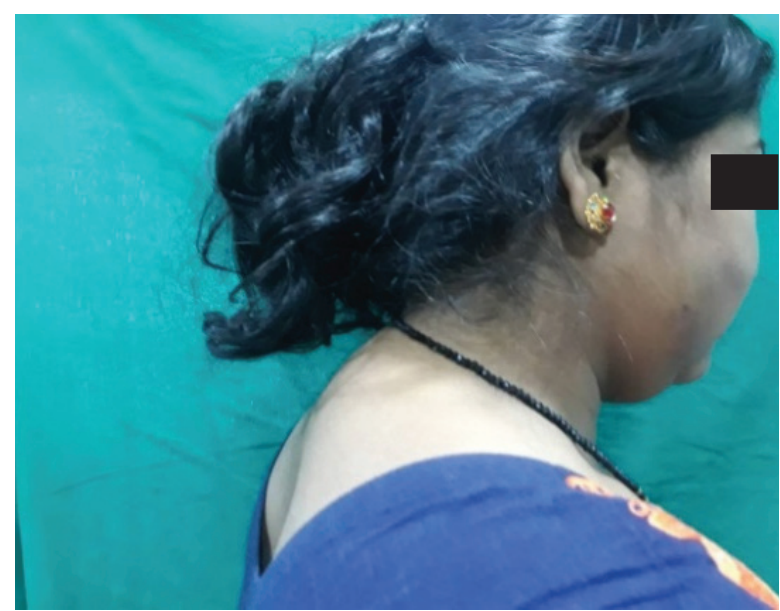

Figure 4: Buffalo hump after treatment 


\section{Discussion}

Topical corticosteroids misuse for various dermatological conditions is a common problem in India and Nepal. ${ }^{2,3,6}$ A nationwide Outpatient Department (OPD) based multi-centric study in India, among patients having facial dermatosis, $14.8 \%$ were using topical steroid, out of which $90.5 \%$ had various side effects due to steroid. $59.3 \%$ of those applying were non-prescriptional out of which $90.3 \%$ were potent/superpotent steroids. ${ }^{7}$ Although systemic side effects are rare with topical applications compared to oral or parenteral forms, prolonged use of topical corticosteroids in larger amounts can causes Cushing's syndrome and suppression of the hypothalamopituitary-adrenal axis (HPA). ${ }^{8,9}$ This is more common in children compared to adults. The reason being 2.5-3 times higher body surface to weight ratio in childrens. ${ }^{6}$ Toxicity also depends on potency, manner and quantity of application, application site and duration. Our patient had applied significant quantity

\section{References}

1. Warner MR, Camisa C. Topical corticosteroids. In: Wolverton SE (ed.) Comprehensive dermatologic drug therapy. 3rd ed. China: Elsevier; 2013.p.487504.

2. Kumar S, Goyal A, YK Gupta. Abuse of topical corticosteroids in India: Concerns and the way forward. J PharmacolPharmacother. 2016 JanMar; 7(1): 1-5.https://doi.org/10.4103/0976500X.179364

3. Jha AK, Karki S, Jha SM. Topical Corticosteroid Abuse in Nepal: Scenario. In: Lahiri K. (eds.) A Treatise on Topical Corticosteroids in Dermatology. Singapore: Springer; 2018 May.p.189-96.https:// doi.org/10.1007/978-981-10-4609-4_18

4. Verma SB Topical corticosteroid misuse in India is harmful and out of control. BMJ. 2015;351:h6079. https://doi.org/10.1136/bmj.h6079

5. Parajuli S, Paudel U, Poudyal A, Pokhrel DB. A clinical study of steroid induced dermatoses. Nepal Journal of Dermatology, Venereology \& Leprology 2018;16:12-6.https://doi.org/10.3126/ njdvl.v16i1.19397 of potent steroid ( $>50 \mathrm{~g} /$ week) at multiple locations including groins, where absorption is high. ${ }^{10}$ HPA axis suppression following corticosteroid is reversible as happened in our case with normalization of serum cortisol after three months of discontinuation of corticosteroids.

\section{Conclusion}

Corticosteroids are prescribed as over the counter drugs in our part of world and patients have very little knowledge about their side effects. Injudicious steroid usage should be discouraged and patients / pharmacist should be well educated about their local and systemic side effects on prolong application. Dermatology society should bring public awareness campaign to educate people and lobby the authority for strict legislation on over the counter steroid sale.

Financial disclosure: None.

Conflict of interest to disclosure: None declared.

6. Sıklar Z, Bostanci I, Atli O, Dallar Y. An infantile Cushing syndrome due to misuse of topical steroid. Pediatr Dermatol. 2004;21:561-3.https:// doi.org/10.1111/j.0736-8046.2004.21508.x

7. Saraswat A, Lahiri K, Chatterjee $M$, Barua $S$, Coondoo A, Mittal A, et al. Topical corticosteroid abuse on the face: $A$ prospective, multicenter study of dermatology outpatients. Indian J Dermatol Venereol Leprol. 2011;77:160-6. https://doi.org/10.4103/0378-6323.77455

8. Abma EM, Blanken R, De Heide LJ. Cushing's syndrome caused by topical steroid therapy for psoriasis. Neth J Med. 2002;60(3):148-50.

9. Young CA, Williams IR, MacFarlane IA. Unrecognised Cushing's syndrome and adrenal suppression due to topical clobetasol propionate. Br J Clin Pract. 1991;45:61-2.

10. Allenby CF, Main RA, Marsden RA, Sparkes CG. Effect on adrenal function of topically applied clobetasol propionate (Dermovate). $\mathrm{Br}$ Med J. 1975;13:619-21.https://doi.org/10.1136/ bmj.4.5997.619 